\title{
The impact of no-tillage cultivation and white mustard as a cover crop on weed infestation and yield of carrot and red beet
}

\author{
Andrzej Borowy ${ }^{1 *}$, Robert Gruszecki², Magdalena Kapłan' \\ 1 Department of Horticultural Nursery and Seed Production, University of Life Sciences in Lublin, S. Leszczyńskiego 58, 20-068 Lublin, Poland \\ ${ }^{2}$ Department of Vegetable Crops and Medicinal Plants, University of Life Sciences in Lublin, S. Leszczyńskiego 58, 20-068 Lublin, Poland
}

\begin{abstract}
In a two-year field experiment, no-tillage cultivation using white mustard (Sinapis alba L. 'Bardena'), $30 \mathrm{~kg} \mathrm{ha}^{-1}$, as a cover crop did not influence emergence of red beet (Beta vulgaris L. 'Czerwona Kula REW') and had a favorable effect on emergence of carrot (Daucus carota L. 'Berlikumer 2 - Perfekcja REW'). However, further growth of both vegetables was significantly slower under no-tillage cultivation. Both vegetables produced a higher yield of roots and the diameter of these roots was bigger under conventional cultivation. The effect of cultivation method on the content of total nitrogen, phosphorus, potassium, calcium and magnesium in carrot and red beet leaves varied, while the content of dry matter, monosaccharides and total sugars was significantly higher in the roots of both vegetables harvested under no-tillage cultivation. The number of weeds growing on no-tilled plots covered with mustard mulch 4 weeks after seed sowing was lower by about $75 \%$, but their fresh weight was higher more than 6 times in comparison to that under conventional cultivation. This was caused by the emergence of wintering and winter hardy weeds in places not covered by mustard plants in the autumn of the year preceding the cultivation of vegetables. Next year, they started to grow in the early spring and some of them produced a considerable amount of fresh weight and attained the flowering stage in the middle of April.
\end{abstract}

Keywords: tillage system; emergence; plant growth; macronutrients; dry weight; monosaccharides; total sugars

\section{Introduction}

Soil is a limited, non-renewable natural resource and its protection is an important task in sustainable agriculture [1]. No-tillage cultivation using cover crops fits the principles of this agricultural system [2-4]. Cover crops have several advantages and one of them is protection against weeds [5]. In Poland's natural conditions, white mustard can be used in vegetable cultivation as a non-winter hardy cover crop [6-9]. Seeded in the beginning of August, it grows fast and covers the soil surface entirely before the arrival of the winter. After the crop is killed by frost, its residues protect the soil against erosion and weeds for several months [7-9]. White mustard contains glucosinolates which inhibit the germination of weed seeds [10]. Moreover, some of its cultivars can suppress nematodes [11] which cause considerable damage in carrot and red beet cultivation [12]. The properties of no-tilled soil covered with cover crop undergo changes and this can influence the germination of seeds, then the uptake of mineral nutrients by cultivated plants, and finally also their growth, yield and chemical composition [9,13-15]. Soil properties

\footnotetext{
* Corresponding author. Email: andrzej.borowy@up.lublin.p
}

Handling Editor: Elżbieta Weryszko-Chmielewska are of significant importance in the cultivation of carrot [16] and to a lesser degree in the cultivation of red beet [17]. Until now, there has been only sparse information about the response of carrot and red beet to no-tillage cultivation using cover crops and especially using white mustard as a cover crop $[13,14,18,19]$. According to Leavitt et al. [20], some cover crops decrease weed density but also reduce vegetable yields in no-tillage production. The purpose of this experiment was to study the influence of white mustard as a cover crop on emergence, growth, yield and chemical composition of carrot and red beet as well as on the occurrence of weeds in these crops under no-tillage cultivation.

\section{Material and methods}

The field experiment was conducted at the Felin Experimental Farm ( $215 \mathrm{~m}$ above sea level, $51^{\circ} 14^{\prime} \mathrm{N}$ latitude, $22^{\circ} 38^{\prime} \mathrm{W}$ longitude) belonging to the University of Life Sciences in Lublin in the years 2009-2011. The plants were cultivated on podzolic soil derived from dusty medium clay with a $\mathrm{pH}$ of 6.6 and an organic matter content of $1.8 \%$. In the middle of the second week of August of the year preceding the cultivation of carrot and red beet, $76.8 \mathrm{~m}^{2}(6 \times 12.8 \mathrm{~m})$ of the experimental field was fertilized with $80 \mathrm{~kg} \mathrm{~N} \mathrm{ha}^{-1}$ 
ammonium nitrate, $22 \mathrm{~kg} \mathrm{P} \mathrm{ha}^{-1}$ super-phosphate, and $83 \mathrm{~kg}$ $\mathrm{K} \mathrm{ha}^{-1}$ potassium chloride. Then, the field was tilled with a rotary cultivator and seeded in rows with $30 \mathrm{~kg} \mathrm{ha}^{-1}$ white mustard (Sinapis alba L.) 'Bardena' seeds, with a $12 \mathrm{~cm}$ distance between rows. The other part of the field was ploughed $20 \mathrm{~cm}$ deep in November, whereas in the middle of April of the following year it was fertilized with the same phosphorus and potassium fertilizers as the field with white mustard and then cultivated with a rotary cultivator $15 \mathrm{~cm}$ deep. Nitrogen was applied in the form of ammonium nitrate: $70 \mathrm{~kg} \mathrm{~N} \mathrm{ha}^{-1}$ was mixed with the upper soil layer before sowing carrot and red beet seeds and $70 \mathrm{~kg} \mathrm{~N} \mathrm{ha}^{-1}$ was applied as a top dressing at the end of May. The no-tilled plots covered with mustard mulch were fertilized with $70 \mathrm{~kg} \mathrm{~N} \mathrm{ha}^{-1}$ one week after sowing carrot and red beet seeds and again with $70 \mathrm{~kg}$ $\mathrm{N} \mathrm{ha}^{-1}$ at the end of May.

The emergence, growth and development of mustard as well as of carrot and red beet plants were observed. At the end of October, the average height of the mustard crop was determined and then plants growing on $1 \mathrm{~m}^{2}$ were dug up and their fresh weight was measured.

At the beginning of winter, mustard plants were killed by frost and in the middle of April the standing mustard stems were rolled and formed mulch covering the surface of the no-tilled plots. At the beginning of the third week of April, seeds of carrot (Daucus carota L.) 'Berlikumer 2 - Perfekcja REW' (3.0 kg ha-1) and seeds of red beet (Beta vulgaris L.) 'Czerwona Kula REW' (10.0 kg ha' ${ }^{-1}$ ) were sown by hand in rows $6 \mathrm{~m}$ long and with a $40 \mathrm{~cm}$ distance between them. The rows in the no-tilled plots covered with mulch were made using a hand hoe. The area of one plot was $9.6 \mathrm{~m}^{2}$ and there were 4 rows in the plot and 4 plots in one treatment.

In the middle of May, when the weeds were at the cotyledon or first true leaf stage, the number and fresh weight of weeds growing in the interrows in a $0.4 \mathrm{~m}^{2}$ area were measured. Then, the plots were weeded by hand and afterwards the number of carrot and red beet seedlings emerged in $1 \mathrm{~m}$ of each row was determined. Two complementary weedings were performed at the end of May and three weeks later. During the vegetation period, the length of the longest leaf of twenty carrot and red beet plants growing in each row was measured at the end of the third week of June, July, and August.

At the beginning of August, samples of fully developed carrot and red beet leaves were collected and then the content of total nitrogen (distillation method), phosphorus (colorimetric method), potassium (flame photometry), calcium (flame photometry), and magnesium (atomic absorption spectrometry) in air-dry leaves was determined at the Regional Chemical-Agricultural Station in Lublin.

Both vegetables were harvested in the middle of September. Immediately after harvest, the weight of whole plants with leaves was measured. Then, the leaves were cut off and the carrot roots were sorted into two size classes: with a diameter smaller than $20 \mathrm{~mm}$ and with a diameter bigger than $20 \mathrm{~mm}$. The red beet roots were sorted also into two size classes: with a diameter smaller and bigger than $40 \mathrm{~mm}$. Next, the samples of carrot roots with a diameter bigger than $20 \mathrm{~mm}$ and those of red beets with a diameter bigger than $40 \mathrm{~mm}$ were collected and the content of dry matter (oven dry method), total sugars and monosaccharides (Schoorl-Luff's method) was determined in these samples in the Laboratory of the Department of Vegetable Crops and Medicinal Plants, University of Life Sciences in Lublin.

The results were studied by analysis of variance and the significance of differences was determined at a 0.05 probability level.

\section{Results}

The emergence of cover crop depended on precipitation in the middle of August. In 2009 the quantity of rainfall was enough for good emergence of mustard which covered entirely the soil surface, leaving no place for the growth of weeds. In 2010 there was little rain in this period and the emergence of white mustard was much worse. At the end of October mustard plants were in full bloom and attained a height of $93 \mathrm{~cm}$ in 2009 and $91 \mathrm{~cm}$ in 2010, while their fresh weight was $4136.2 \mathrm{~g} \mathrm{~m}^{-2}$ and $3231.4 \mathrm{~g} \mathrm{~m}^{-2}$, respectively. The plants were killed by frost in the winter and after rolling them in April next year their residues covered 93\% of the soil surface in 2010 and $75 \%$ in 2011 . Mustard mulch decomposed slowly and in September it covered $25 \%$ and $10 \%$ of the soil surface, respectively, in these two years of the study. It had a significant effect on the number and fresh weight of weeds growing 4 weeks after sowing of carrot and red beet seeds (Tab. 1). At that time, 453 weeds on average grew on $1 \mathrm{~m}^{2}$ of the conventionally cultivated plots and the number of weeds growing on the mulched plots was reduced by about 75\%, but their fresh weight was bigger more than 6 times in comparison to that under conventional cultivation. This was caused by the appearance of numerous wintering and winter hardy species and especially annual blue grass (Poa annua L.), shepherd's purse [Capsella bursa-pastoris (L.) Med.], and common chickweed [Stellaria media (L.) Vill.] in places not covered by mustard plants in the fall of 2010. Next year, they started to grow in the early spring and some of them attained the flowering stage in the middle of April. The perennial species of broadleaf plantain (Plantago major L.) and common dandelion (Taraxacum officinale Web.) grew in the experiment occasionally, but they were more numerous on the no-tilled plots.

The emergence of carrot and red beet started 9-11 days after seed sowing and continued for several days. The emergence of weeds also began at this time and weed competition was dangerous especially for slow growing carrot seedlings. The mustard mulch did not protect the rows against weed infestation and their weeding was almost as much labourconsuming as the weeding of the rows in the conventionally tilled plots. The effect of mulch on weed infestation decreased gradually together with the decomposition of mustard residues, but with time the competitiveness of carrot and red beet plants against weeds increased. Their leaves covered the soil surface in the first half of July, leaving no place for weeds. In the second half of the cultivation period, only individual specimens of tall growing weeds appeared occasionally among carrot and red beet plants.

No-tillage cultivation using cover crops did not influence the emergence of red beet and had a favorable effect on the 


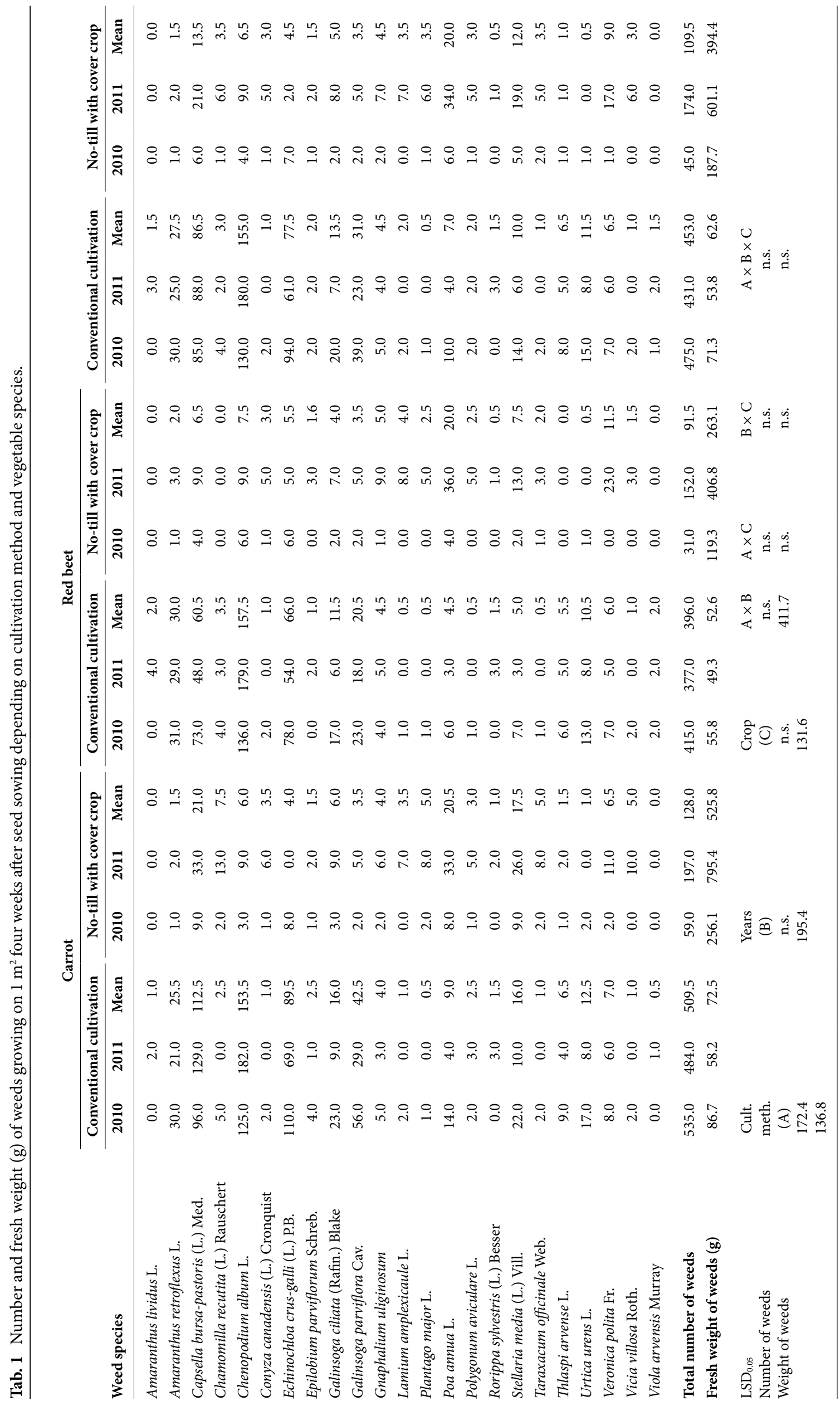


emergence of carrot (Tab. 2). However, it had a significant unfavorable effect on further growth of both vegetables (Tab. 3). From the beginning, their leaves grew slower under no-tillage cultivation and at the end of the vegetation period the leaves of carrot and red beet cultivated conventionally were $8.1 \mathrm{~cm}$ and $4.3 \mathrm{~cm}$ longer, respectively. The response of carrot was more significant. Under no-tillage cultivation, the reduction in its leaves growth was $45 \%, 47 \%$, and $29 \%$ in successive measurements, while in the case of red beet it was $11 \%, 29 \%$, and $12 \%$ in comparison to leaf growth under conventional tillage. This effect was most visible in July and then decreased.

Tab. 2 Effect of cultivation method on emergence of carrot and red beet in 2010 and 2011 (number of seedlings in one running meter of row).

\begin{tabular}{|c|c|c|c|c|c|c|}
\hline \multirow[b]{2}{*}{ Method of cultivation } & \multicolumn{3}{|c|}{ Carrot } & \multicolumn{3}{|c|}{ Red beet } \\
\hline & 2010 & 2011 & Mean & 2010 & 2011 & Mean \\
\hline Conventional & 93 & 119 & 106 & 71 & 83 & 77 \\
\hline No-till with cover crop & 114 & 126 & 120 & 79 & 92 & 86 \\
\hline Mean & 104 & 123 & 113 & 75 & 88 & 82 \\
\hline \multicolumn{7}{|l|}{$\mathrm{LSD}_{0.05}$} \\
\hline Method of cultivation (A) & & 13.4 & & & n.s. & \\
\hline Year (B) & & 18.2 & & & 11.7 & \\
\hline $\mathrm{A} \times \mathrm{B}$ & & n.s. & & & n.s. & \\
\hline
\end{tabular}

Method of cultivation did not influence the content of total nitrogen, phosphorus, potassium and magnesium in carrot leaves in the middle of the vegetation period, whereas the content of calcium was significantly higher under notillage cultivation (Tab. 4). The content of all macronutrients analyzed, except for magnesium, was significantly higher in the first year of the study. It was also dependent, except for potassium, on the interactions between cultivation method and year. In the case of red beet, the content of total nitrogen was higher under no-tillage, while the content of phosphorus and calcium was higher under conventional cultivation (Tab. 5). The content of potassium and magnesium was independent of cultivation method. The content of total nitrogen was higher and the content of potassium, calcium and magnesium was lower in the first year of cultivation, while the content of phosphorus did not depend on this factor. The content of all macroelements, except for magnesium, was also dependent on the interaction between the method and year of cultivation.

The yield of carrot plants with leaves as well as the total yield of roots and the yield of roots with a diameter bigger than $20 \mathrm{~mm}$ were significantly higher under conventional cultivation. The yield of roots with a diameter smaller than $20 \mathrm{~mm}$ did not depend on cultivation method. All the types of carrot yield depended significantly on the year of study (Tab. 6). Similarly, the yields of red beet were also dependent on the year of study (Tab. 7). Total yield of red beet roots and

Tab. 3 Effect of cultivation method on the length of carrot and red beet leaves (cm).

\begin{tabular}{|c|c|c|c|c|c|c|c|c|c|c|c|c|c|c|}
\hline \multirow{3}{*}{$\begin{array}{l}\text { Date of } \\
\text { measurement }\end{array}$} & \multicolumn{6}{|c|}{ Carrot } & \multirow[b]{3}{*}{ Mean } & \multicolumn{6}{|c|}{ Red beet } & \multirow[b]{3}{*}{ Mean } \\
\hline & \multicolumn{3}{|c|}{$\begin{array}{l}\text { Conventional } \\
\text { cultivation }\end{array}$} & \multicolumn{3}{|c|}{$\begin{array}{l}\text { No-tillage with } \\
\text { cover crop }\end{array}$} & & \multicolumn{3}{|c|}{$\begin{array}{l}\text { Conventional } \\
\text { cultivation }\end{array}$} & \multicolumn{3}{|c|}{$\begin{array}{l}\text { No-tillage with cover } \\
\text { crop }\end{array}$} & \\
\hline & 2010 & 2011 & Mean & 2010 & 2011 & Mean & & 2010 & 2011 & Mean & 2010 & 2011 & Mean & \\
\hline June $19-20$ & 5.7 & 6.3 & 6.0 & 3.1 & 3.4 & 3.3 & 4.7 & 9.9 & 10.6 & 10.3 & 9.1 & 9.2 & 9.2 & 7.0 \\
\hline July $17-19$ & 17.5 & 19.4 & 18.5 & 9.3 & 10.3 & 9.8 & 14.2 & 18.3 & 19.7 & 19.0 & 13.4 & 13.6 & 13.5 & 13.9 \\
\hline August $18-20$ & 26.8 & 29.7 & 28.3 & 19.1 & 21.3 & 20.2 & 24.3 & 35.1 & 37.7 & 36.4 & 31.9 & 32.4 & 32.2 & 28.3 \\
\hline Mean & 16.7 & 18.5 & 17.6 & 10.5 & 11.7 & 11.1 & 14.3 & 21.1 & 22.6 & 21.9 & 18.1 & 18.4 & 18.3 & 20.1 \\
\hline $\begin{array}{l}\mathrm{LSD}_{0.05} \\
\text { Method of } \\
\text { cultivation (A) }\end{array}$ & & & 4.51 & & & & & & & 3.58 & & & & \\
\hline $\begin{array}{l}\text { Date of } \\
\text { measurement }(\mathrm{B}) \\
\mathrm{A} \times \mathrm{B}\end{array}$ & & & 8.36 & & & & & & & 6.64 & & & & \\
\hline
\end{tabular}

Tab. 4 Effect of cultivation method on the content of macronutrients in air-dry carrot leaves (\% of air-dry weight).

\begin{tabular}{|c|c|c|c|c|c|c|c|c|c|c|c|c|c|c|c|}
\hline \multirow[b]{2}{*}{ Cultivation method } & \multicolumn{3}{|c|}{ N-total } & \multicolumn{3}{|c|}{$\mathbf{P}$} & \multicolumn{3}{|c|}{$\mathbf{K}$} & \multicolumn{3}{|c|}{$\mathrm{Ca}$} & \multicolumn{3}{|c|}{ Mg } \\
\hline & 2010 & 2011 & Mean & 2010 & 2011 & Mean & 2010 & 2011 & Mean & 2010 & 2011 & Mean & 2010 & 2011 & Mean \\
\hline Conventional & 3.25 & 2.48 & 2.87 & 0.41 & 0.32 & 0.37 & 4.89 & 4.63 & 4.76 & 2.83 & 2.76 & 2.80 & 0.21 & 0.23 & 0.22 \\
\hline No-till with cover crop & 2.74 & 2.93 & 2.84 & 0.38 & 0.34 & 0.36 & 5.02 & 4.27 & 4.65 & 3.05 & 2.92 & 2.99 & 0.17 & 0.25 & 0.21 \\
\hline Mean & 3.00 & 2.71 & 2.86 & 0.40 & 0.33 & 0.37 & 4.96 & 4.45 & 4.71 & 2.94 & 2.84 & 2.89 & 0.19 & 0.24 & 0.22 \\
\hline \multicolumn{16}{|l|}{$\operatorname{LSD}_{0.05}$} \\
\hline Method of cultivation (A) & & n.s. & & & n.s. & & & n.s. & & & 0.09 & & & n.s. & \\
\hline Year (B) & & 0.08 & & & 0.01 & & & 0.36 & & & 0.09 & & & n.s. & \\
\hline $\mathrm{A} \times \mathrm{B}$ & & 0.31 & & & 0.04 & & & n.s. & & & 0.27 & & & 0.03 & \\
\hline
\end{tabular}


Tab. 5 Effect of cultivation method on the content of macronutrients in air-dry red beet leaves (\% of air-dry weight).

\begin{tabular}{|c|c|c|c|c|c|c|c|c|c|c|c|c|c|c|c|}
\hline \multirow[b]{2}{*}{ Cultivation method } & \multicolumn{3}{|c|}{ N-total } & \multicolumn{3}{|c|}{$\mathbf{P}$} & \multicolumn{3}{|c|}{$\mathbf{K}$} & \multicolumn{3}{|c|}{$\mathrm{Ca}$} & \multicolumn{3}{|c|}{ Mg } \\
\hline & 2010 & 2011 & Mean & 2010 & 2011 & Mean & 2010 & 2011 & Mean & 2010 & 2011 & Mean & 2010 & 2011 & Mean \\
\hline Conventional & 3.24 & 2.58 & 2.91 & 0.51 & 0.62 & 0.57 & 5.94 & 5.51 & 5.73 & 3.02 & 3.97 & 3.50 & 0.86 & 1.34 & 1.10 \\
\hline No-till with cover crop & 2.97 & 3.10 & 3.04 & 0.58 & 0.45 & 0.52 & 4.97 & 6.13 & 5.55 & 2.88 & 3.25 & 3.07 & 1.04 & 1.12 & 1.08 \\
\hline Mean & 3.11 & 2.84 & 2.98 & 0.55 & 0.54 & 0.55 & 5.46 & 5.82 & 5.64 & 2.95 & 3.61 & 3.28 & 0.95 & 1.23 & 1.09 \\
\hline \multicolumn{16}{|l|}{$\mathrm{LSD}_{0.05}$} \\
\hline Method of cultivation (A) & & 0.12 & & & 0.04 & & & n.s. & & & 0.15 & & & n.s. & \\
\hline Year (B) & & 0.12 & & & n.s. & & & 0.35 & & & 0.15 & & & 0.05 & \\
\hline $\mathrm{A} \times \mathrm{B}$ & & 0.45 & & & 0.17 & & & 1.12 & & & 0.63 & & & n.s. & \\
\hline
\end{tabular}

Tab. 6 Effect of cultivation method on carrot yield $\left(\mathrm{kg} \times 100 \mathrm{~m}^{-2}\right)$.

\begin{tabular}{|c|c|c|c|c|c|c|c|c|c|c|c|c|}
\hline \multirow[b]{3}{*}{ Method of cultivation } & & & & \multicolumn{9}{|c|}{ Roots } \\
\hline & \multicolumn{3}{|c|}{ Plants with leaves } & \multicolumn{3}{|c|}{ Total yield } & \multicolumn{3}{|c|}{$\begin{array}{c}\text { Roots with diameter }>20 \\
\mathrm{~mm}\end{array}$} & \multicolumn{3}{|c|}{$\begin{array}{c}\text { Roots with diameter }<20 \\
\text { mm }\end{array}$} \\
\hline & 2010 & 2011 & Mean & 2010 & 2011 & Mean & 2010 & 2011 & Mean & 2010 & 2011 & Mean \\
\hline Conventional & 801.4 & 934.1 & 867.8 & 614.8 & 737.3 & 676.1 & 556.2 & 641.7 & 599.0 & 58.6 & 95.5 & 77.1 \\
\hline No-till with cover crop & 626.3 & 722.0 & 674.2 & 466.7 & 531.9 & 499.3 & 420.1 & 447.9 & 434.0 & 46.6 & 84.0 & 65.3 \\
\hline Mean & 713.9 & 828.1 & 771.0 & 540.8 & 634.6 & 587.7 & 488.2 & 544.8 & 516.5 & 52.6 & 89.8 & 71.2 \\
\hline \multicolumn{13}{|l|}{$\mathrm{LSD}_{0.05}$} \\
\hline Method of cultivation (A) & & & 91.6 & & & 88.4 & & & 55.9 & & & n.s. \\
\hline Year (B) & & & 91.6 & & & 88.4 & & & 55.9 & & & 17.2 \\
\hline$A \times B$ & & & n.s. & & & n.s. & & & n.s. & & & n.s. \\
\hline
\end{tabular}

Tab. 7 Effect of cultivation method on red beet yield $\left(\mathrm{kg} \times 100 \mathrm{~m}^{-2}\right)$.

\begin{tabular}{|c|c|c|c|c|c|c|c|c|c|c|c|c|}
\hline \multirow[b]{3}{*}{ Method of cultivation } & & & & \multicolumn{9}{|c|}{ Roots } \\
\hline & \multicolumn{3}{|c|}{ Plants with leaves } & \multicolumn{3}{|c|}{ Total yield } & \multicolumn{3}{|c|}{$\begin{array}{c}\text { Roots with diameter }>40 \\
\mathrm{~mm}\end{array}$} & \multicolumn{3}{|c|}{$\begin{array}{c}\text { Roots with diameter }<40 \\
\mathrm{~mm}\end{array}$} \\
\hline & 2010 & 2011 & Mean & 2010 & 2011 & Mean & 2010 & 2011 & Mean & 2010 & 2011 & Mean \\
\hline Conventional & 798.6 & 900.1 & 849.4 & 552.6 & 723.1 & 637.9 & 469.7 & 645.7 & 557.7 & 82.9 & 77.5 & 80.2 \\
\hline No-till with cover crop & 779.5 & 840.4 & 810.0 & 507.5 & 598.5 & 553.0 & 407.1 & 526.0 & 466.6 & 100.4 & 72.5 & 86.5 \\
\hline Mean & 789.1 & 670.3 & 829.7 & 530.1 & 660.8 & 595.5 & 438.4 & 585.9 & 512.2 & 91.7 & 75.0 & 83.4 \\
\hline \multicolumn{13}{|l|}{$\mathrm{LSD}_{0.05}$} \\
\hline Method of cultivation (A) & & & n.s. & & & 63.2 & & & 58.5 & & & n.s. \\
\hline Year (B) & & & 80.9 & & & 63.2 & & & 58.5 & & & 12.3 \\
\hline $\mathrm{A} \times \mathrm{B}$ & & & n.s. & & & n.s. & & & n.s. & & & n.s. \\
\hline
\end{tabular}

yield of roots with a diameter bigger than $40 \mathrm{~mm}$ depended significantly on the method of cultivation, whereas yield of plants with leaves and yield of roots with a diameter smaller than $40 \mathrm{~mm}$ were not dependent on this factor.

Carrot and red beet roots harvested under no-tillage cultivation contained significantly more dry matter, monosaccharides and total sugars in comparison to conventionally tilled roots. Moreover, the content of these components depended on the year of study, except for monosaccharides in carrot roots (Tab. 8, Tab. 9).

\section{Discussion}

Seeded in the middle of the second week of August, mustard plants grew fast, produced a considerable amount of biomass and covered the soil surface entirely, leaving no place for weed growth. However, the lack of rain after sowing mustards seed can cause poor emergence of mustard and in consequence its worse performance as a cover crop. This agrees with the results obtained by other authors [7-9,11]. In the spring of next year after seeding, the mustard residues 
Tab. 8 Content of dry matter, monosaccharides and total sugars in carrot roots depending on cultivation method.

\begin{tabular}{|c|c|c|c|c|c|c|c|c|c|}
\hline \multirow[b]{2}{*}{ Method of cultivation } & \multicolumn{3}{|c|}{ Dry matter \% } & \multicolumn{3}{|c|}{ Monosaccharides \% f. m. } & \multicolumn{3}{|c|}{ Total sugars \% f. m. } \\
\hline & 2010 & 2011 & Mean & 2010 & 2011 & Mean & 2010 & 2011 & Mean \\
\hline Conventional & 12.9 & 11.4 & 12.2 & 2.04 & 1.36 & 1.70 & 4.62 & 3.96 & 4.29 \\
\hline No-till with cover crop & 13.2 & 12.1 & 12.7 & 1.76 & 2.38 & 2.07 & 5.53 & 5.01 & 5.27 \\
\hline Mean & 13.1 & 11.8 & 12.5 & 1.90 & 1.87 & 1.89 & 5.08 & 4.49 & 4.78 \\
\hline \multicolumn{10}{|l|}{$\mathrm{LSD}_{0.05}$} \\
\hline Method of cultivation (A) & & & 0.45 & & & 0.82 & & & 0.31 \\
\hline Year (B) & & & 0.45 & & & n.s. & & & 0.31 \\
\hline$A \times B$ & & & n.s. & & & n.s. & & & n.s. \\
\hline
\end{tabular}

Tab. 9 Content of dry matter, monosaccharides and total sugars in red beet roots depending on cultivation method.

\begin{tabular}{|c|c|c|c|c|c|c|c|c|c|}
\hline \multirow[b]{2}{*}{ Method of cultivation } & \multicolumn{3}{|c|}{ Dry matter \% } & \multicolumn{3}{|c|}{ Monosaccharides \% f. $\mathrm{m}$. } & \multicolumn{3}{|c|}{ Total sugars \% f. $\mathrm{m}$. } \\
\hline & 2010 & 2011 & Mean & 2010 & 2011 & Mean & 2010 & 2011 & Mean \\
\hline Conventional & 13.9 & 12.5 & 13.2 & 0.45 & 0.32 & 0.39 & 6.27 & 5.83 & 6.05 \\
\hline No-till with cover crop & 14.7 & 13.1 & 13.9 & 0.61 & 0.38 & 0.50 & 6.97 & 6.40 & 6.69 \\
\hline Mean & 14.3 & 12.8 & 13.6 & 0.53 & 0.35 & 0.44 & 6.62 & 6.12 & 6.37 \\
\hline \multicolumn{10}{|l|}{$\mathrm{LSD}_{0.05}$} \\
\hline Method of cultivation (A) & & & 0.53 & & & 0.09 & & & 0.49 \\
\hline Year (B) & & & 0.53 & & & 0.09 & & & 0.49 \\
\hline$A \times B$ & & & n.s. & & & n.s. & & & n.s. \\
\hline
\end{tabular}

covered the majority of the soil surface and protected it well against weeds. Several wintering and winter hardy weeds appeared in places not covered by mustard mulch and such weeds should be removed in the early spring to avoid their competition with cultivated plants. Moreover, numerous weeds emerged in the rows where carrot and red beet were growing and removing these weeds was labour-consuming. A similar effect of mustard mulch on weed infestation in notilled vegetable crops was observed by Mikuła and Borowy $[7,8]$ and Borowy [9]. The obtained results confirm the opinion of Leavitt et al. [20] that weeding of a mulched field cause some problems and sometimes the use of herbicides can be necessary. They also confirm the opinion of Teasdale et al. [21] that cover crops provide early-season weed suppression but not full-season weed control and that early weed suppression provided by cover crop residue permits crops to become established before weeds. Taking into consideration all the positive aspects of cover crops, these results are in line with the opinion of Zimdahl [22] that cover crops can be a part of alternative, non-chemical systems of weed control associated with sustainable agriculture.

Time of emergence of both vegetables was not affected by the method of cultivation. The emergence of red beets in no-tilled soil covered with mustard mulch was as good as in conventionally tilled soil and the emergence of carrot was even better (Tab. 2). These results confirm the data obtained by other authors $[9,15,18]$ and can be explained by good soilseed contact [23] and higher soil moisture of no-tilled soil in the spring $[7,9,13]$. However, the further growth of carrot and red beet plants was slower under no-tillage cultivation and ultimately the yields produced by these plants were also significantly lower. A slower growth and reduced yields of vegetable plants have also been observed under no-tillage cultivation using cover crops in several other experiments [18-20]. The effect of cultivation method on the content of macroelements in carrot and red beet leaves was differentiated by and sometimes depended on the year of study and on the interaction between cultivation method and year. This is in line with the results obtained by Jelonkiewicz and Borowy [15] and Borowy [9]. Carrot and red beet roots from the no-tillage system contained significantly more dry matter, monosaccharides and total sugars than roots cultivated conventionally. Similarly, Borowy and Jelonkiewicz [24] and Borowy et al. [18] found a higher content of dry matter in red beet roots harvested under no-till cultivation. Plants produce more sugars under stress conditions [25] and therefore the results obtained in this experiment indicate that no-till cultivation with cover crop was more stressing for both studied root vegetables than conventional cultivation.

\section{Conclusions}

White mustard is a good cover crop in no-tillage cultivation of carrot and red beet. Its effectiveness in weed control depends on the amount of biomass produced by mustard plants.

No-tillage cultivation using white mustard as a cover crop did not affect the emergence of red beet and had a favorable effect on the emergence of carrot. The further growth of 
no-tilled plants was slower and yields produced by these plants were lower.

The effect of cultivation method on the content of total nitrogen, phosphorus, potassium, calcium and magnesium in carrot and red beet leaves at the time of full growth varied

\section{Acknowledgments}

Research supported by the Ministry of Science and Higher Education of Poland as part of the statutory activities of the Department of Horticultural Nurseries and Seed Production, University of Life Sciences in Lublin.

\section{Authors' contributions}

The following declarations about authors' contributions to the research have been made: concept of the study: $A B$; field research: $A B, R G, M K$; laboratory analyses: $R G, M K$; data analyses: $A B, R G, M K$; writing the manuscript: AB, RG.

\section{Competing interests}

No competing interests have been declared.

\section{References}

1. Agenda 21. United Nations Conference on Environment \& Development, Rio de Janeiro, Brazil, 1992 Jun 3-14.

2. Sainju UM, Singh BP. Winter cover crops for sustainable agricultural systems: influence on soil properties, water quality, and crop yields. HortSci. 1997;32(1):21-28.

3. Lal R. Sustainable horticulture and resource management. Acta Hort. 2008;767:19-44.

4. Borowy A. Zastosowanie roślin okrywowych w uprawie warzyw. Materiały Ogólnopolskiej Konferencji Naukowej "Proekologiczna uprawa warzyw - problemy i perspektywy", 2010 Aug 24-25. Siedlce: Akademia Podlaska; 2010. p. 11-18.

5. Boydston RA, Al-Khatib K. Utilizing brassica cover crops for weed suppression in annual cropping systems. In: Singh P, Batish DR, Kohli RK, editors. Sustainable Weed Management. New York, NY: Food Products Press; 2006. p. 77-94.

6. Błażewicz-Woźniak M. Effect of no-tillage and mulching with cover crops on yield of parsley. Folia Hortic. 2005;17(2):3-10.

7. Mikuła A, Borowy A. Wpływ okrywy gorczycowej i uprawy bezorkowej na zachwaszczenie pola, niektóre właściwości fizyczne gleby oraz plonowanie grochu i sałaty. Materiały Konferencyjne "Procesy fizyczne w kształtowaniu środowiska i jakości surowców żywnościowych”. Lublin: Instytut Agrofizyki PAN; 2006. p. 54-55.

8. Mikuła A, Borowy A. Wpływ gorczycy białej jako rośliny okrywowej na zachwaszczenie pola w bezorkowej uprawie trzech wczesnych warzyw. Materiały z XXI Spotkania Zespołu Herbologicznego Komitetu Nauk Ogrodniczych PAN. Olsztyn: KNO PAN; 2007. p. 63-67.

9. Borowy A. Growth and yield of 'Hamburg' parsley under no-tillage cultivation using white mustard as a cover crop. Acta Sci Pol Hortorum Cultus. 2013;12(6):13-12.

10. Oleszek W. Brassicaceae jako rośliny alternatywne umożliwiające kontrolę zachwaszczenia w rolnictwie zachowawczym. Fragm Agronom. 1994;11(4):5-19.

11. Nowakowski M, Franke K. Struktura plonu i oddziaływanie na populację mątwika ziemniaczanego (Globodera rostochiensis) wybranych odmian gorczycy białej uprawianej w plonie głównym. II. Plony biomasy nadziemnej i korzeni oraz zagęszczenie mątwika ziemniaczanego w glebie. Rośliny Oleiste Oilseed Crops. 2013;34(1):85-94.

12. Robak J, Wiech K. Choroby i szkodniki warzyw. Kraków: Plantpress; 1999.

13. Borowy A, Konopiński M, Jelonkiewicz M. Effect of no-tillage and rye mulch on soil properties, weed infestation and yield of carrot and red beet. Annales L'Association Française de Protection des Plantes, XI Colloque International Sur La Biologie Des Mauvaises Herbs, Dijon, France. Dijon: AFPP; 2000. p. 339-345. and sometimes depended on the year of study and on the interaction between these two factors.

No-tillage cultivation using white mustard as a cover crop had a favorable effect on the content of dry matter, monosaccharides and total sugars in carrot and red beet roots.

14. Kęsik T, Konopiński M, Błażewicz-Woźniak M. Reakcja cebuli i marchwi na mulczowanie gleby i siew bezpośredni. Acta Agroph. 2001;45:95-104.

15. Jelonkiewicz M, Borowy A. Growth and yield of cucumber under no-tillage cultivation using rye as a cover crop. Acta Agrobot. 2009;62(1):147-153. http://dx.doi.org/10.5586/aa.2009.017

16. Poniedziałek M. Marchew. In: Orłowski M, editor. Polowa uprawa warzyw. Szczecin: Wydawnictwo Brasika; 2000. p. 251-261.

17. Osińska M. Burak ćwikłowy. In: Orłowski M, editor. Polowa uprawa warzyw. Szczecin: Wydawnictwo Brasika; 2000. p. 277-285.

18. Borowy A, Jelonkiewicz M, Chmielowiec P. Zachwaszczenie oraz plonowanie czterech gatunków warzyw uprawianych metodą bezorkową z zastosowaniem żyta sianego jesienią jako rośliny okrywowej. Rocz AR Pozn Ogrod. 1998;27:27-32.

19. Borowy A. Effect of no-tillage and rye mulch on occurrence of weeds and aphids and on yields of cabbage, carrot and red beet. Acta Hortic. 2004;638:147-150.

20. Leavitt MJ, Sheaffer CC, Wyse DL, Allan DL. Rolled winter rye and hairy vetch cover crops lower weed density but reduce vegetable yields in no-tillage organic production. HortSci. 2011;46(3):387-395.

21. Teasdale JR, Abdul-Baki AA, Mills DJ, Thorpe KW. Enhanced pest management with cover crop mulches. Acta Hortic. 2004;638:135-140.

22. Zimdahl RL. Fundamentals of weed science. New York, NY: Academic Press; 2007.

23. Baker CJ, Saxton KE, Ritchie WR. No-tillage seeding. Science and practice. Cambridge: University Press; 1996.

24. Borowy A, Jelonkiewicz M. Weed infestation and yielding of three vegetable crops in no-tillage cultivation using rye seeded in the spring as a cover crop. Acta Horticulturae et Regiotecturae. 1998;1 suppl:181-182.

25. Abe H. A simple system for cultivating tomatoes with a high sugar content. Achievements of Horticultural Experiment Stations in Japan. Tokyo: Aiko Kikaku Printing Co.; 1994

\section{Wpływ uprawy bezorkowej i gorczycy białej jako rośliny okrywowej na zachwaszczenie oraz plonowanie marchwi i buraka ćwikłowego}

\section{Streszczenie}

W dwuletnim doświadczeniu polowym uprawa bezorkowa $\mathrm{z}$ użyciem gorczycy białej (Sinapis alba L. 'Bardena') jako rośliny okrywowej, wysiewanej na początku drugiej dekady sierpnia w ilości $30 \mathrm{~kg} \mathrm{ha}^{-1}$, nie miała wpływu na wschody buraka ćwikłowego (Beta vulgaris L. 'Czerwona Kula REW') i miała korzystny wpływ na wschody marchwi (Daucus carota L. 'Berlikumer 2 - Perfekcja REW'). Jednakże dalszy wzrost obu warzyw był istotnie wolniejszy na poletkach uprawianych metodą bezorkową. Ostatecznie plon korzeni obu warzyw uprawianych tą metodą był niższy i korzenie te miały mniejszą średnicę niż w uprawie tradycyjnej. Wpływ metody uprawy na zawartość azotu ogólnego, fosforu, potasu, wapnia i magnezu w liściach obu warzyw był zróżnicowany. Korzenie marchwi i buraka ćwikłowego uprawiane metodą bezorkową zawierały istotnie więcej suchej masy, cukrów prostych i cukrów ogółem. Liczba chwastów rosnących na poletkach uprawianych metodą bezorkową i okrytych mulczem gorczycznym, oznaczona 3 tygodnie po siewie nasion warzyw, była o około $75 \%$ mniejsza, lecz ich świeża masa była ponad sześciokrotnie większa w porównaniu do liczby i świeżej masy chwastów rosnących na poletkach uprawianych tradycyjnie. Było to spowodowane wschodami chwastów zimujących i zimotrwałych w miejscach nie okrytych przez rośliny gorczycy podczas jesieni poprzedzającej uprawę warzyw. Chwasty te rozpoczynały wzrost wczesną wiosną następnego roku i niektóre z nich wytwarzały znaczną masę i osiągały fazę kwitnienia w połowie kwietnia. 